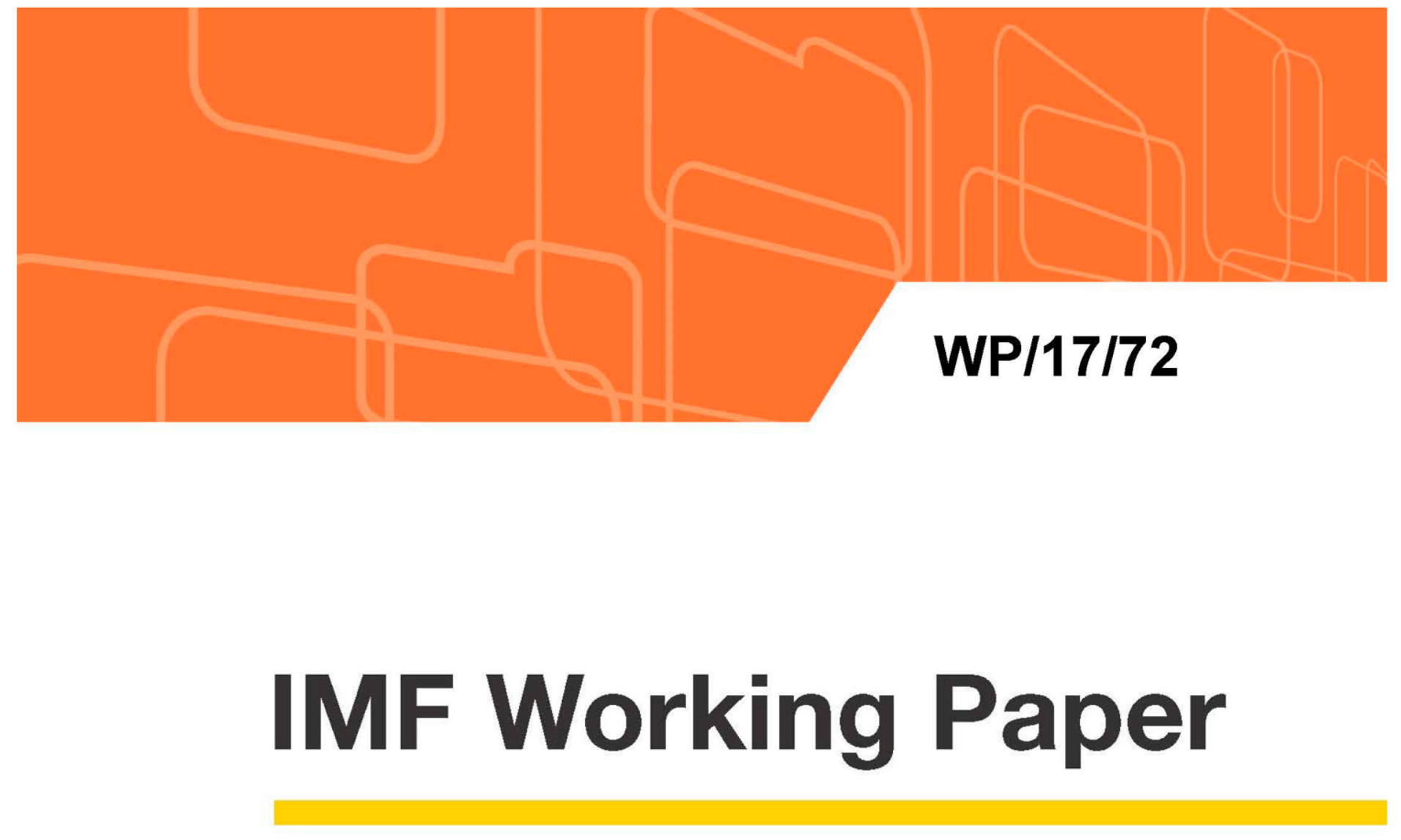

\title{
Excessive Private Sector Leverage and Its Drivers: Evidence from Advanced Economies
}

by Mariusz Jarmuzek and Rossen Rozenov

IMF Working Papers describe research in progress by the author(s) and are published to elicit comments and to encourage debate. The views expressed in IMF Working Papers are those of the author(s) and do not necessarily represent the views of the IMF, its Executive Board, or IMF management.

$$
\text { I N T E R N A T I O N A L M O N E T A R Y F U N D }
$$




\section{WP/17/72}

\section{IMF Working Paper}

\section{Excessive Private Sector Leverage and Its Drivers: Evidence from Advanced Economies}

by Mariusz Jarmuzek and Rossen Rozenov

IMF Working Papers describe research in progress by the author(s) and are published to elicit comments and to encourage debate. The views expressed in IMF Working Papers are those of the author(s) and do not necessarily represent the views of the IMF, its Executive Board, or IMF management.

$$
\text { I N T E R N A T I O N A L M O N E T A R Y F U N D }
$$




\title{
IMF Working Paper
}

Fiscal Affairs Department

\section{Excessive Private Sector Leverage and Its Drivers: Evidence from Advanced Economies $^{1}$}

\author{
Prepared by Mariusz Jarmuzek and Rossen Rozenov
}

Authorized for distribution by Catherine Pattillo

March 2017

\section{IMF Working Papers describe research in progress by the author(s) and are published to elicit comments and to encourage debate. The views expressed in IMF Working Papers are those of the author(s) and do not necessarily represent the views of the IMF, its Executive Board, or IMF management.}

\begin{abstract}
Nonfinancial private sector debt increased significantly in advanced economies prior to the global financial crisis and, with a few exceptions, deleveraging has been limited. Furthermore, in some countries households and corporations have continued to accumulate debt. Drawing on the literature, the paper aims to provide a quantitative assessment of the gaps between actual and sustainable levels of debt and to identify the key factors that drive excessive borrowing. Results suggest that variables that are typically found important in studies focusing on borrowing decisions, are also relevant for explaining the debt sustainability gaps.
\end{abstract}

JEL Classification Numbers: C23 C26 D12 D14 G32 H25 H31 H32

Keywords: household and corporate leverage; corporate capital structure; taxation; private debt sustainability

Author's E-Mail Address: mjarmuzek@imf.org; rrozenov@imf.org

\footnotetext{
${ }^{1}$ The authors would like to express gratitude to Marialuz Moreno Badia for encouragement and guidance. The authors would also like to thank, without implicating, David Amaglobeli, Martin Cihak, Julian Chow, Carlos Cuerpo, Rupa Duttagupta, Emilio Fernandez-Corugedo, Sanjeev Gupta, Shafik Hebous, Dyna Heng, Jun Il Kim, Tonny Lybek, Cathy Pattillo, Tigran Poghosyan, Abdelhak Senhadji, Artur Swistak, Yi Xiong, and FAD seminar participants for useful comments and discussions. Kyungla Chae and Young Kim provided excellent research assistance, while Nadia Malikyar provided excellent editorial and administrative support. Any remaining errors are our own.
} 


\section{Contents}

I. Introduction

II. Conceptual Framework

A. Assessing Debt Overhang

B. Explaining Private Debt

C. Identifying Gaps

III. Assessing Debt Overhang

A. Households

B. Non-financial Corporations

IV. Explaining Debt Overhang $\underline{14}$

A. Households

B. Non-financial Corporations

C. Robustness Checks

V. Conclusions And Policy Implications

References

Figures

1. Debt to Asset Ratios. 12

2. Household Debt and Sustainability Gaps

3. Corporate Debt and Sustainability Gaps

Tables

1. Factors Associated with Household Debt Overhang $\underline{16}$

2. Factors Associated with Corporate Debt Overhang

Appendices

I. Data Sources 


\section{INTRODUCTION}

Nonfinancial private sector debt has increased significantly in developed economies since the early 2000s. Driven by rapid financial liberalization, growing banking interconnectedness and easing access to credit, household and corporate sector debt rose by 35 percent of GDP in developed economies in the six years leading up to the global financial crisis (IMF, 2016). As a result, it reached almost 200 percent of GDP in 2009, an exceptionally high level by historical standards. The credit boom was not limited to the U.S. mortgage sector but was broad-based within the group of advanced countries, as well as in some emerging market economies, with more than half of the debt on the balance sheet of households (IMF, 2016).

High private debt can have a substantial adverse impact on macroeconomic performance and stability. It hinders the ability of households to smooth consumption and affects investment of corporations. In addition, elevated debt levels can create vulnerabilities as well as amplify and transmit macroeconomic and asset price shocks throughout the economy (Sutherland and Hoeller, 2012). Excessive private debt increases the likelihood of a financial crisis, especially when it is driven by asset price bubbles fueled by lending. The subsequent deleveraging could be potentially disruptive for economic activity. As shown by Jorda and others (2016), long-term growth prospects deteriorate significantly following debt-related financial crises. Furthermore, the accelerated pace of private debt accumulation can lead to economic and financial instability, which often coincides with great risk-taking and poorly regulated and supervised financial sector (Sahay and others, 2015).Finally, spillovers from private balance sheets to the public sector due to government interventions, either direct in the form of targeted programs for debt restructuring or indirect through the banking sector, weaken the fiscal position and increase interest rates. All the above factors may potentially compromise public debt sustainability.

While the literature on explaining private sector borrowing is large and expanding further, there are fewer studies on private debt overhang. Several papers building on various strands of theoretical literature employ micro-level and cross-country data to explain household and corporate borrowing. However, there is limited empirical work on assessing excessive borrowing in quantitative terms, with the notable exception of the work by Cuerpo and others (2015) and by Albuquerque and others (2015) who provide analyses for household debt overhang in developed economies and the US states, respectively. To our knowledge, there is neither empirical work on assessing quantitatively excessive borrowing in the corporate sector beyond analyses focusing on thresholds, nor on identifying the factors behind such borrowing decisions by households and corporates.

This paper intends to fill in some of the gaps in the literature. We first ask the question whether there is debt overhang in household and corporate sectors and answer it by extending the work by Cuerpo and others (2015) on measuring excessive leverage for households to the corporate sector. ${ }^{2}$ We subsequently ask the question of what drives excessive indebtedness of households and corporations and answer it by extending the work by Albuquerque and others

\footnotetext{
${ }^{2}$ In this paper, we use the terms "debt overhang", "excessive debt" and "excessive leverage" interchangeably.
} 
(2015) on household debt and by ECB (2013) on corporate debt to a sample of developed economies. In empirical work, we broadly follow the strategy implemented by IMF (2003).

The paper shows that private sector debt overhang is relatively large, with significant heterogeneity across developed economies, and identifies some of its main drivers. Household excessive leverage is found to be higher in countries with lower interest rates and higher share of working population, but importantly also in countries with rising house prices and greater uncertainty as captured by unemployment. Corporate debt overhang is estimated to be higher in countries with lower profitability, stronger insolvency frameworks and absence of thin capitalization rules.

The reminder of the paper is organized as follows. Section II provides an overview of the theoretical and empirical literature on household and corporate borrowing that forms the basis for the identification structure in the subsequent empirical work. Section III presents the methodology underlying the quantitative assessment of debt overhang and its drivers across developed economies. Section IV investigates the drivers of debt overhang in the household and corporate sectors. Section V concludes and provides some tentative policy implications.

\section{Conceptual Framework}

This section provides a conceptual framework for the empirical analysis undertaken in the subsequent sections. Based on a comprehensive literature review, it discusses key approaches to assessing household and corporate debt, and identifies main factors explaining the borrowing decisions.

\section{A. Assessing Debt Overhang}

Measuring excessive debt is challenging since it involves an assessment of the debtor's repayment capacity. Such assessments typically rely on metrics that relate the level of debt (or debt service) to the borrower's current and future income. Using debt to income ratios alone, however, omits an important aspect of debt sustainability - the strength of the borrower's balance sheet. Debt can be repaid not only from future income but also by selling assets; hence, solvency indicators, such as the debt to asset ratio, are widely used in debt sustainability analyses. ${ }^{3}$ The importance of assets also stems from their role as collateral against which households and firms can borrow. Debt to assets and debt to income ratios are typically compared to some benchmark, either based on distributional characteristics of the population (e.g. average or median debt ratios) or specified as a threshold value beyond which debt is deemed excessive.

An alternative approach to evaluating potential deleveraging pressures is proposed by Cuerpo and others (2015), building on the sustainability concept developed by Arrow and others (2004). The original analysis in Arrow and others (2004) is concerned with assessing the level of consumption and the authors propose a sustainability criterion which requires

\footnotetext{
${ }^{3}$ In principle, individuals can also borrow against their human capital; however, this aspect of the borrower's debt repayment capacity entails difficult theoretical and measurement issues and is not pursued here.
} 
intertemporal social welfare to be non-decreasing. The latter is equivalent to requiring "genuine investment", defined as the change in the quantity of society's capital assets multiplied by the shadow value of the asset, to be non-negative. In the context of gauging private sector's leverage, the sustainability criterion can be interpreted as a requirement for net worth not to decline over time. The concept can be made operational by requiring the leverage ratio to be stationary. In other words, debt should evolve in line with assets over the medium and long run. Cuerpo and others (2015) note that typically the ratio of debt to total nominal assets follows a stationary trajectory. However, nominal assets are not necessarily a good indicator of the debt carrying capacity of households and non-financial corporations (NFC) because of large swings in asset prices. An asset price bubble would increase the value of the collateral and would lead to higher debt. A more prudent measure of leverage is, therefore, a ratio of debt to assets stripped of valuation effects (also referred to as notional assets).

\section{B. Explaining Private Debt}

\section{Households}

The theoretical framework to analyze household borrowing builds on the lifecycle/permanent-income hypothesis. Models developed by Modigliani and Brumberg (1954) and Friedman (1957) provide an intertemporal setting for analyzing consumption, which is mainly concerned with the household debt profile over the life-cycle. Households dissave in the early part of their working life, and their consumption is financed by borrowing. As the households age and their labor income grows, indebtedness decreases and assets are accumulated. Economies with relatively young populations will therefore tend to be associated with larger levels of household indebtedness, while an increase in expected income tends to shift desired consumption upward and also contribute to household debt.

The effect of changes in interest rates on net borrowing can, however, be ambiguous. A decline in interest rates reduces the return on the household's asset holdings, but at the same time it decreases the cost of borrowing and increases the present value of future labor income (Debelle, 2004). The impact of these two different effects is likely to vary across households depending on their stage in the life-cycle. Older households with large accumulated wealth and near the end of their working life are likely to be more affected by the lower returns on their wealth, whereas younger households are likely to be more influenced by the lower cost of borrowing (Muellbauer, 1994).

The traditional analytical framework can be extended to account for income uncertainty. Friedman (1957) suggested that the propensity to spend out of permanent income is a decreasing function of income uncertainty, an idea which was further developed by Hall (1978). ${ }^{4}$ Building on this work, Carroll and Dunn (1997) postulate that income uncertainty should be a relevant consideration for household borrowing, with a reduction in uncertainty lessening the need for precautionary reserves and consequently boosting borrowing.

\footnotetext{
${ }^{4}$ Deaton (1992) and Muellbauer (1994) provide an extensive exposition of the uncertainty in the context of the life-cycle/permanent-income frameworks.
} 
Ludvigson (1999) develops a formal model suggesting that borrowing could provide liquidity to smooth consumption in the presence of temporary income shocks.

Housing is another important factor. The life-cycle/permanent-income framework suggests that an increase in house prices may boost household consumption and reduce savings through the wealth effect, resulting in more borrowing by households (Muellbauer, 2007). Combining the life-cycle/permanent-income hypothesis with the financial accelerator model developed by Bernanke and others (1999), Aoki and others (2004) demonstrate how house prices may affect household borrowing through the collateral effect. This channel works through the role of housing capital as collateral available to homeowners, so that house price increases may generate additional equity and improve the possibility for households to borrow against their housing equity. The tax system may also have an impact on household debt through mortgage interest payment deductibility and differential tax treatment of the purchase of housing versus other assets (Debelle, 2004). In particular, the interaction of high tax rates, high nominal interest rates, and mortgage interest payment deductibility may strongly encourage debt-financed purchase of housing (Poterba, 1984).

Going beyond demand-side factors, financial liberalization and market imperfections provide additional insights. Incorporating liquidity constraints in the traditional framework implies that households can borrow less than they would optimally do, but with financial liberalization relaxing quantity constraints and/or lowering price of credit, they can actually borrow potentially more (Debelle, 2004). Specifically, relaxing credit conditions in the housing markets by allowing households to borrow against accumulated housing equity may lead to higher household debt (Miles, 1992). More generally, market imperfections can induce excessive borrowing through collateral values (Lorenzoni, 2008). Finally, access to finance and the degree of financial market development may affect the availability of funding and the ability of households to borrow (Sahay and others, 2015).

Extending supply-side factors to account for the role of institutions can also be important. The logic to include institutions among the factors influencing indebtedness is that they are capable of affecting the supply side through affecting the behavior of financial intermediaries (Coletta and others, 2014). There are two main theoretical frameworks that determine how much private credit a financial system would extend to households and corporations (Djankov and others, 2007). The first approach, pursued by Townsend (1979), Aghion and Bolton (1992), and Hart and Moore (1994, 1998), hinges on the argument that private credit is determined by the power of creditors through the degree to which they can enforce repayments, takeover of collateral or gain control over corporates. The second one, developed by Jaffee and Russell (1976) and Stiglitz and Weiss (1981), centers on the importance of information. The more information creditors have on borrowers and their credit history, the more willingly they would extend loans to those borrowers.

Empirical work based on the traditional framework for household borrowing generally confirms the relevance of income, interest rates, and to some extent, of demographics. Barnes and Young (2003) and Tudela and Young (2005) use simple calibrated models based on microdata to show that changes in these variables can to a certain extent explain household indebtedness in the US and UK, respectively. In fact, these models have some features of 
housing embedded, but still cannot account for actual developments in terms of household borrowing; for example, the rising indebtedness in the US in the presence of high interest rates, lower income growth, and aging population. The findings on the impact of demographics are mixed, as shown by Davies and others (2010) and Coletta and others (2014).

Incorporating uncertainty proves to be important. As shown by Carroll and Dunn (1997) for the US and by Fernandez-Corugedo and Muellbauer (2006) for the UK, accounting for uncertainty in the models helps to explain household indebtedness. The empirical strategy followed in both papers is to include unemployment among the independent variables in the model.

In addition to uncertainty, there is a strong case for incorporating various aspects of housing. Evidence from Dynan and Kohn (2007) for the US and Fernandez-Corugedo and Muellbauer (2006) for the UK, suggests the need to include house prices along traditional variables such as income, interest rate, and demographics. Both studies find that rising house prices are associated with higher borrowing by households. Campbell and Rocco (2007) show, based on microdata for the UK, that the wealth effect associated with higher house prices translates into higher consumption as the population ages, which may in turn lead to lower savings and higher borrowing. Aoki and others (2004) and Almeida and others (2006) present crosscountry evidence that links higher prices through the collateral effect in the form of the financial accelerator mechanism to higher household borrowing. There is not enough supporting evidence for the importance of housing-related tax incentives though, as shown by Cerutti and others (2015) who examine in a cross-country context if mortgage interest payment deductibility is associated with household leverage.

The literature also provides empirical support for the relevance of financial liberalization and market imperfections, although mainly based on country-specific studies. FernandezCorugedo and Muellbauer (2006) construct a measure of financial liberalization covering a wide spectrum of factors with a focus on credit availability and find that it plays an important role in lending to households in the UK. Dynan and Kohn (2007) link the increase in household borrowing in the US to financial liberalization as well. One aspect of liberalization that received attention is the effect of mortgage securitization on interest rates, with evidence from Jameson and others (1992) and Kolari and others (1998), suggesting lowering of the spread between mortgage rates and risk-free rates. Miles (1992) presents findings for the UK and US that financial liberalization in the form of house equity withdrawals affects savings, which may in turn prompt more borrowing. Yet another aspect is capital account liberalization, which is often associated with lending booms through facilitating the import of financial services and increasing competition in the financial system (Cottarelli and others, 2005), All the above results, however, are mostly based on country-specific studies, so there is not much cross-country evidence on the relevance of financial liberalization and market imperfections for household leverage.

Finally, the role of institutions also finds some support. Djankov and others (2007) examine the importance of the power of creditors and the role of information in explaining differences in private credit across a large number of countries and find that the strength of the legal 
system in the form of credit protection, as well as the strength of information sharing institutions, tend to be associated with higher private credit. In a similar spirit, Coletta and others (2014) provide evidence for the relevance of type and quality of legal framework for household debt across OECD countries.

\section{Non-financial Corporations}

The theoretical framework developed by Modigliani and Miller (1958) has served as a benchmark for research on capital structure of corporations. The framework demonstrates that capital structure has no impact on the value of firms, nor on their cost of capital, so it is often referred to as the leverage irrelevance framework. This prediction is however made under the assumptions of perfect capital markets and a neutral tax system, and once these assumptions are relaxed, capital structure has a bearing on the value of firms and their cost of capital (ECB, 2013).

There are two main strands of research departing from the leverage irrelevance concept. The first one is the trade-off theory, developed by Myers (1977) and Myers and Majluf (1984), that states that firms balance their debt and equity positions by accounting for the trade-offs between the value of tax advantages resulting from additional debt and the costs of potential financial distress. This implies that the higher the maximum tax rate, the higher the debt, and the higher the costs of distress, the lower the debt. The second strand is the pecking order theory, developed by Myers and Majluf (1984) and Myers (1984), that emphasizes the importance of asymmetric information for the capital structure. Asymmetric information increases financing costs, so that corporates prefer internal financing over external financing, and because debt financing involves lower costs and no outside shareholders, corporates prefer debt over equity. Myers (1984) contrasts the two theories and concludes that they are equally good in explaining the firms' capital structure.

In addition to the two main hypotheses discussed above, there is also a theoretical strand postulating some role for institutions. Analogously to the importance of institutions for household borrowing, theoretical frameworks embedding the power of creditors and information developed by Aghion and Bolton (1992) and Hart and Moore (1994, 1998) as well as by Jaffee and Russell (1976) and Stiglitz and Weiss (1981) provide ways to analyze the determinants of credit extension.

The trade-off theory is broadly supported by empirical research. Graham (1996) provides evidence that changes in debt are positively correlated with the firm's tax rate. Further, Graham (2003) shows that in order to benefit from tax advantages on interest expenses, firms facing high tax rates use debt more intensively than low-tax-rate firms. Thornhill and others (2004) argue that firms with high collateral assets should have greater access to bank funding compared to those with more intangible assets.

The pecking order theory also attracts some support from the data. Rajan and Zingales (1995) as well as Fama and French (2002) present evidence for a negative relationship between corporate leverage and profitability. These findings are confirmed by Hall and others (2000) as well as Hall and others (2004). 
There have been attempts to combine the trade-off and pecking order frameworks in empirical work. Graham and Harvey (2001) conduct a survey of the practice of corporate finance and find some broad support for both theories. De Jong and others (2011) test the trade-off theory against the pecking order theory and show two regions where the two have conflicting results. The pecking order theory is a better description of the firm behavior for issuing decisions, while the trade-off theory is a stronger predictor of firms' capital structure decisions. Almeida and Campello (2010) argue for the need to go beyond the standard pecking order theory, pointing out that the negative relation between profitability and external financing cannot be explained by asymmetric information arguments only.

There has also been an increasing effort to incorporate country-specific institutional factors related to capital structure determination. Rajan and Zingales (1995) argue based on a sample of firms in developed economies that although firm-specific factors significantly affect the capital structure of corporations, several country-specific institutional factors also play an important role. In the same spirit, Demirguc-Kunt and Maksimovic (1999) compare capital structures across developed and developing economies and find that institutional differences explain a large portion of the variation in corporate debt. More specifically, quality of law enforcement is found by De Jong and others (2008) and Giannetti (2003) to be correlated with corporate debt, while Fan and others (2010) and De Jong and others (2008) show that the strength of the insolvency framework tends to be associated with corporate leverage.

Among other institutional aspects, the importance of tax regimes has been extensively examined. In addition to the evidence from the trade-off theory by Graham (1996) and Graham (2003), Rajan and Zingales (1995) show that tax advantages associated with leverage are positively correlated with corporate debt, a result which is echoed by Fan and others (2010). Thin capitalization rules are set up to counteract these adverse effects related to tax advantages and are generally found to be broadly effective, as shown by de Mooij and Hebous (2016), Blouin and others (2014), and Graham and Harvey (2001).

\section{Identifying Gaps}

This paper aims to addresses some of the gaps in the literature related to factors behind excessive indebtedness. First, we extend the work on measuring debt overhang by Cuerpo and others (2015) to the corporate sector and provide estimates of debt overhang for both household and corporates for a sample of developed economies. Second, building on the extensive literature, we identify key factors driving debt decisions and test whether these factors can explain the gaps between actual and sustainable debt based on cross-country evidence. Third, we provide some evidence that policy can play a role in addressing the debt overhang in both household and corporate sectors.

\section{Assessing Debt Overhang}

As noted above, the calculation of sustainability gaps, following Cuerpo et al. (2015), involves the construction of notional, or deflated assets. At the aggregate level, notional total assets are obtained as the sum of deflated financial and non-financial assets where: 
- Deflated financial assets are obtained by adding financial asset transactions to the stock of financial assets in the initial year. This approach to constructing the notional leverage ratio, implicitly assumes that actual debt is at equilibrium in the initial year. Clearly, this assumption is not necessarily satisfied, so the absolute values of the debt sustainability gaps based on notional assets and liabilities should be interpreted with caution. However, for cross-country comparisons focusing on the evolution of excessive leverage over time, this caveat applies to a lesser extent. Moreover, if the initial year is relatively distant, the effect of the initial stock would be relatively small.

- Deflated non-financial assets are calculated by applying real growth rates to the initial stock of non-financial assets. Real growth rates in turn are calculated as the difference between nominal growth rates of non-financial assets and the real change in house prices (in our case approximated by the difference between nominal house price inflation and CPI) in the case of households. For non-financial corporations, we take a weighted average of the real house price and the investment deflator. For the purposes of this analysis equal weights are assumed, based on the composition of non-financial assets of companies (buildings vs. other fixed assets) in the countries for which detailed information is available. However, the results are not very sensitive to the choice of weights for the deflator. In calculating the notional nonfinancial assets based on real growth rates we do not account for depreciation. This is a simplifying assumption which should not affect materially the results; moreover, we are primarily interested in the evolution of debt sustainability gaps over time, not so much in their level.

The sum of deflated financial and non-financial assets represents total notional assets. Similar to financial assets, deflated debt is obtained by adding debt transactions to the initial stock of debt. Deflated sustainable debt is then calculated as deflated debt in the initial year, increased by the change in notional assets and corrected for transitory changes in the nominal debt-to-asset ratio (which is assumed stationary). In other words, deflated debt is considered sustainable when it evolves with deflated assets. Excessive leverage is measured by the difference between the actual and sustainable debt. This may be a conservative estimate of sustainable debt given that valuation effects for assets are typically much higher than those for debt. ${ }^{5}$ As an alternative, we construct a sustainability metric which entails adjusting assets and debt only for revaluations that deviate from fundamentals captured by a trend, along the lines of IMF (2016). The two methodologies produce similar results in terms of leveraging/deleveraging but clearly, the size of the gaps is lower when gauged by the modified metric. ${ }^{6}$ However, as stated earlier, the focus of our study is not so much on the size of the sustainability gaps, which is difficult to estimate precisely, but rather on their evolution. The approach based on stationarity of the notional leverage is not directly comparable to other existing metrics which makes it hard to establish its robustness;

\footnotetext{
${ }^{5}$ For example, for households, the implicit debt valuation effects (calculated as the difference between nominal and deflated debt) are about 2 percent on average for the sample, whereas the asset valuation effects are about 16 percent.

${ }^{6}$ The empirical findings on the drivers of excessive debt are broadly similar for the two alternative measures.
} 
nevertheless, the individual results it produces are qualitatively similar to what more conventional indebtedness indicators would suggest.

The methodology described above is applied to a sample of advanced economies, largely based on OECD data on balance sheets, transactions in assets and liability and house prices. National data sources have been used on a few occasions to fill data gaps. ${ }^{7}$ For GDP, consumer prices and investment deflators the source is IMF's World Economic Outlook. There are 16 advanced countries in the sample in the case of households and 15 countries in the case of non-financial corporations. ${ }^{8}$ For most countries, data are available from 1995, with only a few starting between 1997 and 2000.

Overall, data provide broad support to the hypothesis of stationarity of the ratio of debt (defined here as the sum of loans and debt securities) to nominal assets, a key assumption underpinning the methodology (Figure 1). However, in the case of households, the debt to notional asset ratio exhibits an upward trend in the period leading up to the financial crisis. It has declined thereafter but is still above the level in 2000 and the gap between the two remains relatively wide.

Figure 1. Debt to Asset Ratios.

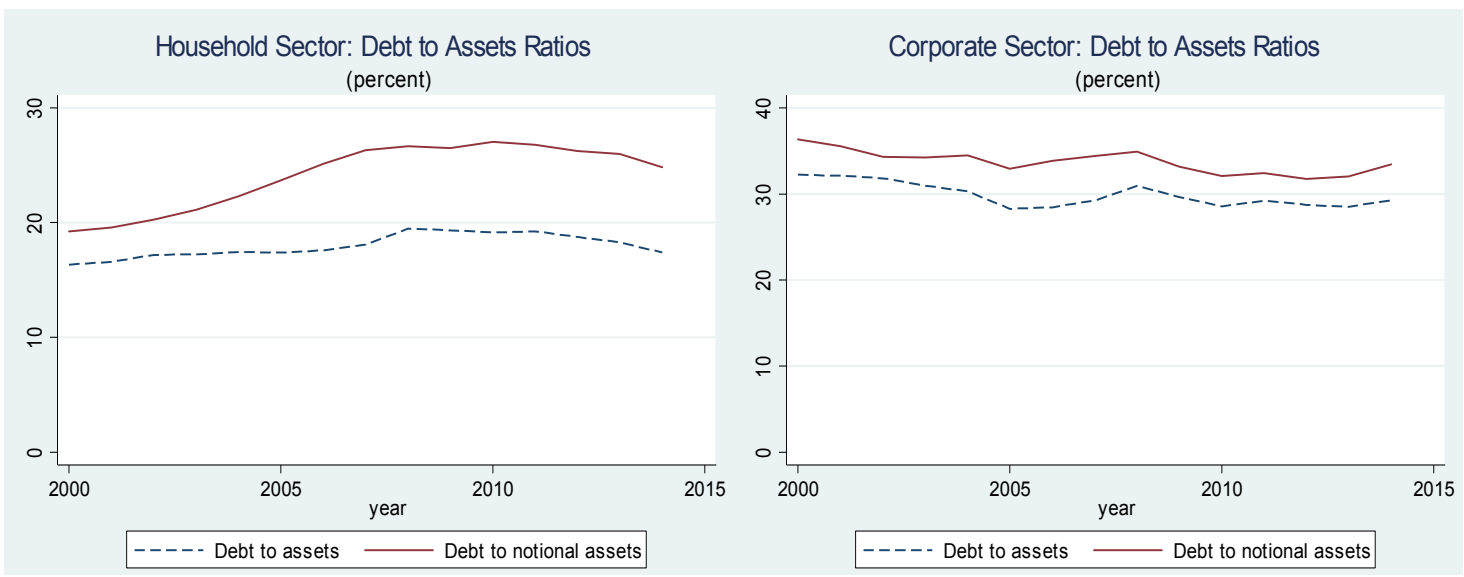

Source: Authors' calculations

\section{A. Households}

The results from the household debt sustainability analysis are summarized in Figure 2. The left panel, compares the average actual debt to GDP ratio to the sustainable debt to GDP ratio for the 16 advanced economies in the sample. The dynamics of the two series suggest that the measured sustainability gap has widened in period leading up to the financial crisis, which reflects the favorable growth performance and associated optimism during that period. The average gap remains large and furthermore, it has increased slightly in the last few years. The averages, however, mask significant cross-country differences. In a number of countries, the

\footnotetext{
${ }^{7}$ Specifically, national sources have been used for Spain, Portugal, Canada and Australia.

8 Time series for the stock of non-financial assets of corporates in Portugal were not readily available.
} 
accumulated sustainability gaps are quite large and in some cases they continue to grow. In contrast, in countries which did not experience asset price booms, the gaps have been negative. The latter result is partly driven by a decline in real house prices in those economies, which translates into higher real growth of non-financial assets throughout most of the sample.

\section{Figure 2. Household Debt and Sustainability Gaps}

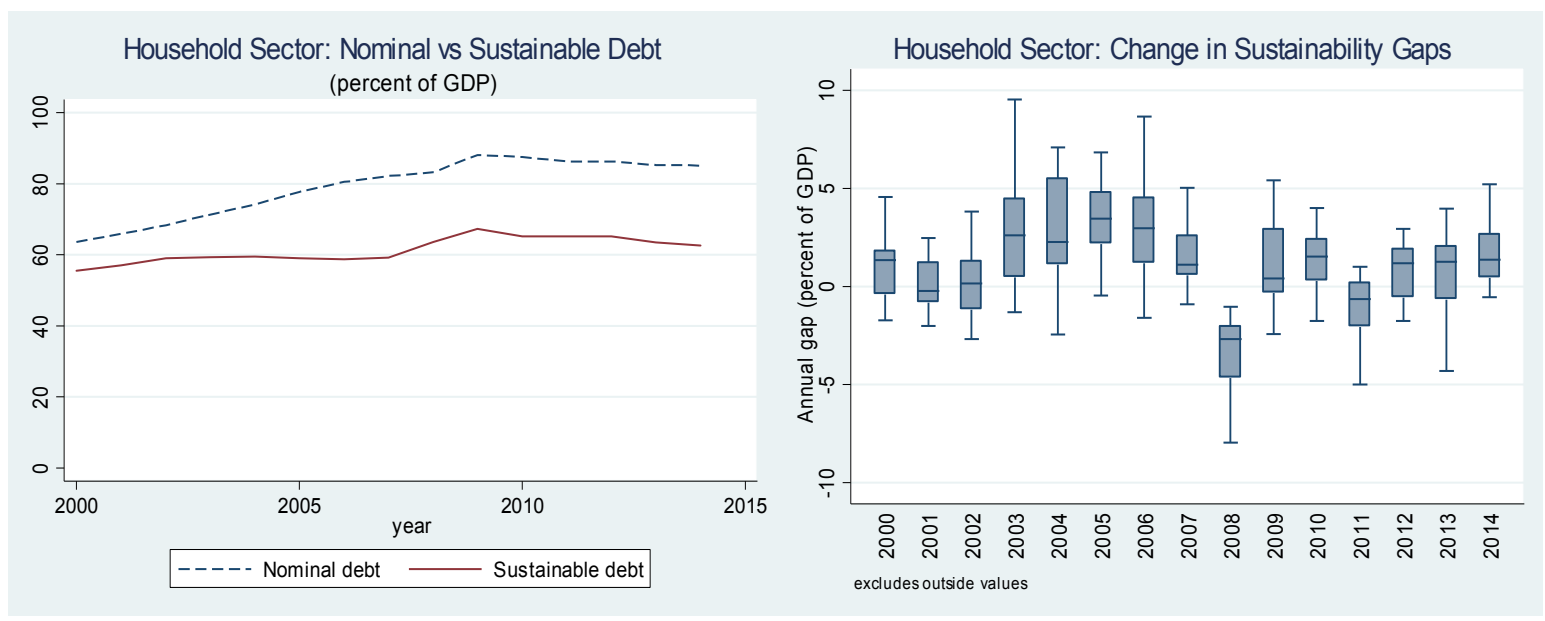

Source: Authors' calculations

The relatively steep increase in the sustainable debt ratio in 2008-09 reflects two main factors: (i) in most cases, the ratio of nominal debt to nominal assets increased due to decline in the value of assets, and (ii) the growth in deflated assets was higher on average in the considered period, which could be explained with the decrease in house prices. In 2009, the ratio of sustainable debt to GDP was enhanced further by the decline in nominal GDP in a number of advanced economies.

The right panel of Figure 2 captures the heterogeneity of results for the annual changes in excessive leverage. There is significant variation in the annual sustainability gaps, both across countries and over time, especially in 2005-2006 (build-up of debt) and 2008-2009 (deleveraging). In the last three years of available data, the median gap has been small but still positive. While households in some countries managed to reduce their indebtedness relative to the peak levels recorded prior to the financial crisis, in others the process of leveraging continues.

\section{B. Non-financial Corporations}

For non-financial corporations, results suggest smaller gaps between actual and sustainable debt on average compared to households (Figure 3, left panel). The steep rise in the debt ratio in 2006-08 was largely driven by the fast accumulation of debt in the corporate sector; the average nominal debt increase in this period was more than two times higher than in the previous three years. 
Individual results vary considerably as suggested by the right panel of Figure 3, with annual gaps generally positive in the period 2003-2007 and negative in 2008 and 2011. Overall, the cross-country variation of the sustainability gaps is larger than in the case of households. Relative to the pre-crisis period, NFCs in nearly half of the countries have increased their leverage over the last several years. Yet, some countries where the gap was relatively high in the pre-crisis period have managed to deleverage.

Figure 3. Corporate Debt and Sustainability Gaps
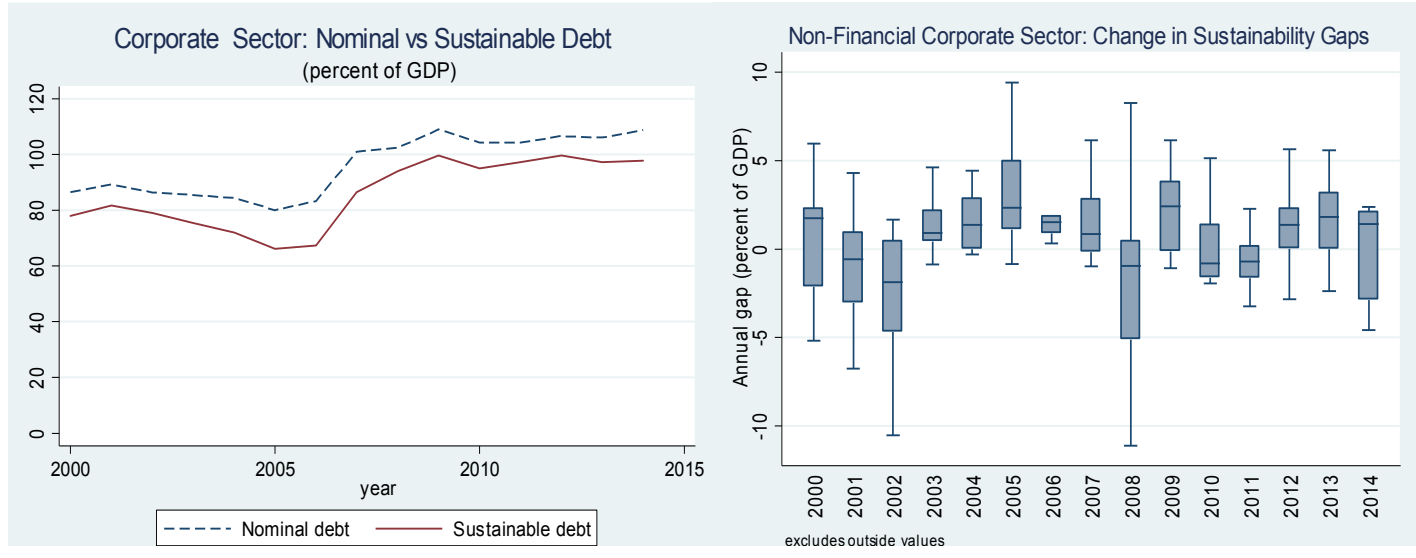

Source: Authors' calculations

\section{EXPLAINING DEBT OVERHANG}

In view of the magnitude and heterogeneity of the debt sustainability gaps, it is of interest to examine the factors that may explain debt overhang across countries.

\section{A. Households}

\section{Methodology}

Drawing on the literature on household borrowing, we identify four groups of variables that are potential candidates for explaining the differences in excessive debt. The groups include: (i) income, interest rate, and demographics; (ii) housing and related tax incentives; (iii) uncertainty; and (iv) institutions.

We conduct a dynamic multivariate regression analysis to consider simultaneously various variables that are likely to be correlated with household borrowing. Specifically, following the existing literature, we estimate the following equation:

$$
\Delta h d o_{i t}=\alpha_{0}+\alpha_{1} i n c_{i t}+\alpha_{2} i r_{i t}+\alpha_{3} d m_{i t}+\alpha_{4} h p_{i t}+\alpha_{5} u n_{i t}+\alpha_{6} i n_{i t}+\alpha_{7} m i d_{i t}+\varepsilon_{i t}
$$

where $h d o i t$ is household debt overhang in country $i$ at time $t$, measured by the gap between actual and sustainable debt ratios, incit is income per capita, $i_{i t}$ is the long-term lending rate (approximated with the mortgage rate), $d m_{i t}$ is the share of working population in total population, $h p_{i t}$ is house price dynamics, $u n$ is unemployment, $i n_{i t}$ is a set of institutional 
variables in the form of rule of law, and midit $_{i t}$ is a dummy variable taking the value 1 if a country has mortgage interest deductibility in place. Data sources are described in Appendix I (Table 1).

We attempt to account for reverse causality issues. Following Albuquerque and others (2015) as well as Djankov and others (2007), we estimate the baseline specification assuming that house prices and the rule of law can be potentially endogenous. To address this challenge, we use the instrumental variables estimation technique and employ lagged values of house prices and the rule of law as well as voice and accountability and political stability indicators as instruments. ${ }^{9}$

\section{Results}

Based on the regression results, there is only partial support for the traditional framework hinging on the life-cycle/permanent-income hypothesis (Table 1). The negative association between interest rate and household borrowing points to the dominance of the balance sheet effect, so that lower rates make it possible to service larger debt. This evidence is consistent with the one obtained by Fernandez-Corugedo and Muellbauer (2006), Barnes and Young (2003), and Albuquerque and others (2015). Although demographics in the form of the share of working population is positively correlated with household excessive leverage, it is statistically significant in only some of the specifications. This finding, however, is broadly in line with the results obtained by Coletta and others (2014) and Davies and others (2010). The correlation between income and household debt is very weak and not statistically significant. This may be due to the measurement issues because GDP per capita does not arguably capture income available at the consumer level, with most studies employing disposable income. In addition, the unemployment rate that we use as a proxy for income uncertainty may also capture income expectations, as postulated by Fernandez-Corugedo and Muellbauer (2006) and applied by Albuquerque and others (2015).

The results confirm the importance of house prices for household borrowing. There is quite strong evidence suggesting that house prices are positively correlated with household debt overhang. This is consistent with the findings by Fernandez-Corugedo and Muellbauer (2006), Dynan and Kohn (2007), as well as by Aoki and others (2004).

Uncertainty is an important factor in household's borrowing decisions as suggested by theory and confirmed by a number of empirical studies. Following Carroll and Dunn (1997), we use unemployment as a proxy for income uncertainty. Our results provide solid evidence that income uncertainty is indeed correlated with household excessive leverage, with higher unemployment rates associated with lower sustainability gaps. This is in line with the findings in Carroll and Dunn (1997), as well as Fernandez-Corugedo and Muellbauer (2006).

\footnotetext{
${ }^{9}$ Drawing on the political economy literature, voice and accountability as well as political stability indicators shape political power and institutions that in turn shape economic institutions, with the latter typically captured by the rule of law (Acemoglu, 2005, 2016; Acemoglu and Robinson, 2016).
} 
We also find empirical support for the role of institutions. Incorporating the strength of the rule of law in the regressions yields a statistically significant association with household excessive leverage, with the sign consistent with priors. The evidence broadly corroborates the results obtained by Djankov and others (2007) and Coletta and others (2014).

\section{Table 1. Factors Associated with Household Debt Overhang}

\begin{tabular}{|c|c|c|c|c|}
\hline & (1) & (2) & (3) & (4) \\
\hline income per capita & $\begin{array}{l}0.0661 \\
(1.626)\end{array}$ & $\begin{array}{c}0.619 \\
(1.631)\end{array}$ & $\begin{array}{c}1.066 \\
(1.611)\end{array}$ & $\begin{array}{c}1.113 \\
(1.605)\end{array}$ \\
\hline interest rate & $\begin{array}{c}-0.266^{* *} \\
(0.113)\end{array}$ & $\begin{array}{c}-0.231 * * \\
(0.116)\end{array}$ & $\begin{array}{c}-0.266^{* *} \\
(0.114)\end{array}$ & $\begin{array}{c}-0.256^{* *} \\
(0.113)\end{array}$ \\
\hline demographics & $\begin{array}{c}0.128 \\
(0.159)\end{array}$ & $\begin{array}{l}0.278^{*} \\
(0.156)\end{array}$ & $\begin{array}{c}0.338 * * \\
(0.154)\end{array}$ & $\begin{array}{c}0.352 * * \\
(0.156)\end{array}$ \\
\hline house prices & $\begin{array}{c}0.398 * * * \\
(0.0363)\end{array}$ & $\begin{array}{c}0.352 * * * \\
(0.0533)\end{array}$ & $\begin{array}{c}0.352 * * * \\
(0.0511)\end{array}$ & $\begin{array}{c}0.354 * * * \\
(0.0524)\end{array}$ \\
\hline unemployment & & $\begin{array}{c}-0.151^{*} \\
(0.0890)\end{array}$ & $\begin{array}{l}-0.185^{* *} \\
(0.0872)\end{array}$ & $\begin{array}{l}-0.171^{*} \\
(0.0958)\end{array}$ \\
\hline rule of law & & & $\begin{array}{l}5.978 * * \\
(2.522)\end{array}$ & $\begin{array}{l}5.712 * * \\
(2.531)\end{array}$ \\
\hline mortgage deductibility & & & & $\begin{array}{c}0.662 \\
(0.701)\end{array}$ \\
\hline $\mathrm{N}$ & 221 & 221 & 221 & 221 \\
\hline $\begin{array}{l}\text { J-statistic } \\
\text { (p-value) }\end{array}$ & $\begin{array}{c}0.01 \\
0.9219\end{array}$ & $\begin{array}{c}0.532 \\
0.4657\end{array}$ & $\begin{array}{c}1.476 \\
0.6877\end{array}$ & $\begin{array}{c}1.652 \\
0.6476\end{array}$ \\
\hline
\end{tabular}

Source: Authors' calculations

Data do not support the relevance of mortgage interest payment deductibility for household leverage. This finding is in line with results based on cross-country regressions obtained by Cerutti and others (2015). Similarly, Jappelli and Pistaferri (2007) do not find evidence that tax reforms in Italy in the early 1990s, which eliminated the link between after-tax mortgage rates and marginal tax rates, had a significant impact on the demand for mortgage debt. They explain this result with the presence of borrowing constraints or lack of financial information. Measuring the impact of mortgage tax relief on debt, however, is challenging for several reasons. Depending on the design, the effects of mortgage interest deductibility are likely to vary for different households. Poterba and Sinai (2011) document significant disparities in the potential response to a repeal of the mortgage tax incentive across age and income groups. Younger households with few financial assets have little room for portfolio adjustments and would be affected relatively more, whereas older households with substantial financial assets could sell those assets to pay down mortgage debt. In addition, there are measurement issues. As noted earlier, we use a binary classification based on a 
relatively broad definition of deductibility which extends to any special tax treatment of mortgage interest and principal payments. However, practices have varied significantly, both across countries and over time.

\section{B. Non-financial Corporations}

\section{Methodology}

Following the same approach as with households and drawing on the literature review, we identify the following candidates for explaining the differences in sustainability gaps across countries: (i) tax rate and profitability associated with trade-off and pecking order theories; and (ii) institutions.

We consider a number of variables as candidates to be correlated with corporate borrowing. Specifically, we estimate the following dynamic equation:

$$
\Delta c d o_{i t}=\alpha_{0}+\alpha_{1} g r_{i t}+\alpha_{2} c i t_{i t}+\alpha_{3} \operatorname{roa}_{i t}+\alpha_{4} i n s_{i t}+\alpha_{5} t c_{i t}+\varepsilon_{i t}
$$

where $c d o_{i t}$ is corporate debt overhang in country $i$ at time $t$, defined as the difference between actual and sustainable debt ratios, $g r_{i t}$ denotes real GDP growth, cit $_{i t}$ is the top

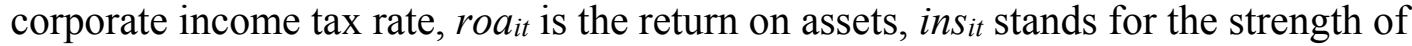
insolvency, and $t c_{i t}$ is a dummy variable taking the value 1 if a country has thin capitalization rules in place. Data sources are described in Appendix I (Table 1).

As with households, we address potential reverse causality issues. Following De Mooij and Keen (2016) and Djankov and others (2007), we estimate the baseline specification assuming that the CIT rate and the strength of insolvency can be potentially endogenous. As instruments, we use lagged values of the CIT rate and the strength of insolvency indicator, in addition to the political stability and absence of violence indicators. ${ }^{10}$

\section{Results}

The results provide support for the pecking order theory. Following the approach which combines the trade-off and pecking order theories, advocated by Graham and Harvey (2001) and by De Jong and others (2011), profitability and tax rate are considered simultaneously in the corporate debt overhang equation. There is strong support for the negative impact of profitability on firms' leveraging decisions, which is in line with the pecking order theory. As Frank and Goyal (2008) report in their survey, firms generally prefer internal finance over external funds, so if investments and dividends are assumed to be fixed, more profitable firms will become more leveraged over time. The evidence is consistent with the results obtained by Rajan and Zingales (1995), Fama and French (2002), and de Mooij and Hebous (2016).

\footnotetext{
${ }^{10}$ Similarly to the rule of law, building on the political economy literature, political stability affects economic institutions, including protection of property rights and related strength of insolvency framework, through political power and institutions (Acemoglu, 2005, 2016; Acemoglu and Robinson, 2016).
} 
There is also some support for the trade-off theory. Tax rates are correlated with the dependent variable, but the relationship does not seem to be very strong. Feld and others (2013) discuss the sources of potential biases and perform meta-regression analysis to synthetize the information from a number of studies. In particular, they argue that the estimates of tax effects are influenced by the tax rate proxy used for identification; marginal tax rates are associated with higher estimates for the tax coefficient than statutory tax rates. Using average tax rates, on the other hand, introduces endogeneity which, if not addressed, would lead to a downward bias in the estimates.

Finally, the importance of institutions is confirmed as well. The strength of insolvency frameworks is significantly correlated with the sustainability gaps, with stronger insolvency arrangements associated with lower excessive leverage. This evidence is consistent with ECB (2013), Fan and others (2010), and De Jong and others (2008). Another important institutional dimension is the tax regime. In this respect, we find strong evidence that countries applying thin capitalization rules are characterized by lower corporate debt overhang which is in line with results obtained by de Mooij and Hebous (2016) and Blouin and others (2014).

Table 2. Factors Associated with Corporate Debt Overhang

\begin{tabular}{|c|c|c|c|c|c|}
\hline & (1) & (2) & (3) & (4) & (5) \\
\hline GDP growth & $\begin{array}{c}49.44^{* * *} \\
(13.43)\end{array}$ & $\begin{array}{c}64.15^{* * *} \\
(14.04)\end{array}$ & $\begin{array}{c}84.07^{* * *} \\
(14.68)\end{array}$ & $\begin{array}{c}84.49 * * * \\
(14.39)\end{array}$ & $\begin{array}{c}86.67^{* * *} \\
(16.55)\end{array}$ \\
\hline CIT & & $\begin{array}{c}0.142 \\
(0.116)\end{array}$ & $\begin{array}{l}0.290^{*} \\
(0.150)\end{array}$ & $\begin{array}{l}0.276^{*} \\
(0.148)\end{array}$ & $\begin{array}{l}0.337^{*} \\
(0.188)\end{array}$ \\
\hline ROA & & & $\begin{array}{c}-42.85 * * * \\
(15.18)\end{array}$ & $\begin{array}{c}-52.70^{* * *} \\
(16.73)\end{array}$ & $\begin{array}{l}-69.62^{*} \\
(35.74)\end{array}$ \\
\hline thin capitalization & & & & $\begin{array}{l}-1.875^{*} \\
(1.004)\end{array}$ & $\begin{array}{c}-4.392^{* * *} \\
(1.001)\end{array}$ \\
\hline insolvency & & & & & $\begin{array}{c}-0.346^{* * *} \\
(0.116)\end{array}$ \\
\hline $\mathrm{N}$ & 261 & 229 & 198 & 198 & 137 \\
\hline $\begin{array}{l}\text { J-statistic } \\
\text { (p-value) }\end{array}$ & & $\begin{array}{c}0.714 \\
0.6999\end{array}$ & $\begin{array}{l}1.382 \\
0.501 \\
\end{array}$ & $\begin{array}{r}2.022 \\
0.3638 \\
\end{array}$ & $\begin{array}{r}3.965 \\
0.4107 \\
\end{array}$ \\
\hline
\end{tabular}

Source: Authors' calculations

\section{Robustness Checks}

We ran a set of robustness checks to examine the sensitivity of our estimates to a different definition of the sustainability gap, outliers, and the lagged dependent variable bias. 
- Definition of the sustainability gap. In addition to annual sustainability gaps, the same set of regressions is estimated based on cumulative sustainability gaps using the limited-information maximum likelihood estimator. The results for both household and corporate sectors do not materially change across the board of various specifications. The tables illustrating this robustness check are presented in Appendix II (Table 1 and Table 4).

- $\quad$ Outliers. We investigate formally the sensitivity of the results to outliers. Following Blanchard and Leigh (2013), we reestimate the baseline set of specifications using robust regression, which down-weighs observations with larger absolute residuals using iterative weighted least squares (Andersen, 2008). Employing this methodology for both household and corporate sustainability gaps results in broadly the same outcome across the board of specifications. The tables illustrating this robustness check are shown in Appendix II (Table 2 and Table 5).

- $\quad$ Lagged dependent variable bias. Estimating a panel data model including the lagged dependent variable with the standard techniques, such as the least squares dummy variable estimator, would lead to inconsistent results when the cross-sectional dimension is not small and the time dimension is finite. We follow Debrun and Kinda (2016) and use the bias-corrected least square dummy variable dynamic panel estimator suggested by Bruno (2005), which approximates the bias inherent to dynamic unbalanced panels and constructs a consistent estimator. Judson and Owen (1999) show that this estimator performs better than other methods, such as the generalized method of moments estimator, when $\mathrm{N}$ is moderately large and $\mathrm{T}$ is relatively small, as in this paper. The tables illustrating this robustness check are given in Appendix II (Table 3 and Table 6).

\section{Conclusions ANd Policy Implications}

The results from our empirical analysis suggest that in a number of advanced economies household and corporate debt has increased to levels that may not be sustainable. Most of the debt build-up took place before the financial crisis, but with a few exceptions, there has been little deleveraging in the post-crisis period. In a number of countries, the gap between actual and sustainable debt, calculated on the basis of notional assets continues to grow. The gaps are larger in the household sector; the borrowing behavior of non-financial corporations does not seem to have changed much on aggregate, although there is significant cross-country heterogeneity.

Drawing on the theoertical literature on household and corporate debt determinants and building on earlier empirical work, we try to identify the main drivers of excessive leverage. Most of the variables that have been found important in previous studies focusing on indebtedness, turn out to be significant in explaining the debt sustainability gaps as well. In particular, low interest rates and unemployment along with high house prices tend to be associated with larger gaps in the case of household. This implies that policymakers should pay attention to excessively low interest rates and inflated house prices to avoid imbalances 
that may utlimately pose risks to macroeconomic stability. While we find evidence for importance of instituions, the tax treatment of mortgage debt does not appear to be significant, althought the latter could be due to difficult measurement issues. Still, this does not mean that there is no role for policies in containing leverage. For example, generous mortgage-related tax incentives that favor ownership over renting can induce excessive borrowing by households and boost asset prices which, as discussed above, are positively correlated with the sustainability gaps. Furthermore, such incentives have important distributional implications and can be costly in terms of foregone revenue for the budget.

In the case of non-financial corporations, profitability is a significant factor behind leveraging, while thin capitalization rules tend to reduce the debt overhang. Thin capitalization rules can be an effective instrument to limit excessive borrowing but they need to be well designed. In many countries such rules provide escape clauses that effectively limit them to related party debt, implying that these measures aim to reduce debt shifting, but do not deal effectively with the debt bias. Introducing a tax system based on allowance for corporate equity (ACE) would not only reduce the incentives to incur debt but would also stimulate investment as it is effectively a tax only on excess returns or rents. There is also some role for institutions because countries with stronger insolvency regimes are typically characterized by lower debt overhang.

Looking forward, a couple of areas merit further research. First, it would be useful to develop a more refined measure of excessive private sector leverage, with assets corrected for transitory valuation effects to account for asset price movemements reflecting fundamentals. In addition, it would also be useful to further advance work on residual endogeneity issues, associated potentially with interest rate, income, and profitability. 


\section{Appendix I. Data Sources and Country Coverage}

Table I. 1. Data Sources

\begin{tabular}{lll}
\hline Abbreviation & Variable & Source \\
inc & income per capita & WEO \\
ir & long-term lending rate (approximated with the mortgage rate) & national central banks \\
$\mathrm{dm}$ & share of working population in total population & WEO \\
$\mathrm{hp}$ & house price dynamics & OECD \\
un & unemployment & WEO \\
in & rule of law & World Bank \\
& dummy variable taking the value 1 if a country has mortgage interest \\
mid & deductibility in place & IBFD \\
& & Centre for Business Taxation, \\
cit & top corporate income tax rate & Oxford University \\
roa & return on assets & OECD \\
ins & strength of insolvency & World Bank \\
& dummy variable taking the value 1 if a country has thin capitalization \\
tc & rules in place & IBFD \\
\hline
\end{tabular}

Table I. 2. Country Coverage

\begin{tabular}{ll}
\hline Households & Non-financial corporations \\
Australia & Australia \\
Austria & Austria \\
Belgium & Belgium \\
Canada & Canada \\
Denmark & Denmark \\
Finland & Finland \\
France & France \\
Germany & Germany \\
Italy & Italy \\
Japan & Japan \\
Netherlands & Netherlands \\
Portugal & Spain \\
Spain & Sweden \\
Sweden & United Kingdom \\
United Kingdom & USA \\
USA & \\
\hline
\end{tabular}




\section{Appendix II. Robustness Checks}

Table II. 1

\begin{tabular}{|c|c|c|c|c|}
\hline & (1) & (2) & (3) & (4) \\
\hline cumulative debt overhang lag & $\begin{array}{c}0.984 * * * \\
(0.0193)\end{array}$ & $\begin{array}{l}0.975 * * * \\
(0.0211)\end{array}$ & $\begin{array}{c}0.978 * * * \\
(0.0207)\end{array}$ & $\begin{array}{c}0.978^{* * *} \\
(0.0207)\end{array}$ \\
\hline income per capita & $\begin{array}{c}-0.111 \\
(1.672)\end{array}$ & $\begin{array}{c}0.373 \\
(1.650)\end{array}$ & $\begin{array}{c}0.731 \\
(1.666)\end{array}$ & $\begin{array}{c}0.747 \\
(1.661)\end{array}$ \\
\hline interest rate & $\begin{array}{c}-0.275^{* *} \\
(0.116)\end{array}$ & $\begin{array}{c}-0.249 * * \\
(0.117)\end{array}$ & $\begin{array}{c}-0.301^{* *} \\
(0.117)\end{array}$ & $\begin{array}{c}-0.292^{* *} \\
(0.116)\end{array}$ \\
\hline demographics & $\begin{array}{l}0.0508 \\
(0.205)\end{array}$ & $\begin{array}{c}0.163 \\
(0.192)\end{array}$ & $\begin{array}{c}0.234 \\
(0.191)\end{array}$ & $\begin{array}{c}0.249 \\
(0.193)\end{array}$ \\
\hline house prices & $\begin{array}{c}0.392^{* * *} \\
(0.0418)\end{array}$ & $\begin{array}{c}0.349 * * * \\
(0.0635)\end{array}$ & $\begin{array}{c}0.347 * * * \\
(0.0624)\end{array}$ & $\begin{array}{c}0.350 * * * \\
(0.0637)\end{array}$ \\
\hline unemployment & & $\begin{array}{c}-0.150 \\
(0.0945)\end{array}$ & $\begin{array}{c}-0.181^{*} \\
(0.0942)\end{array}$ & $\begin{array}{l}-0.168 \\
(0.103)\end{array}$ \\
\hline rule of law & & & $\begin{array}{c}6.198^{* *} \\
(2.501)\end{array}$ & $\begin{array}{c}5.988^{* *} \\
(2.516)\end{array}$ \\
\hline mortgage deductibility & & & & $\begin{array}{c}0.625 \\
(0.694)\end{array}$ \\
\hline $\mathrm{N}$ & 221 & 221 & 221 & 221 \\
\hline $\begin{array}{l}\text { J-statistic } \\
\text { (p-value) }\end{array}$ & $\begin{array}{c}0.007 \\
0.9332\end{array}$ & $\begin{array}{l}0.568 \\
0.451\end{array}$ & $\begin{array}{c}1.417 \\
0.7015\end{array}$ & $\begin{array}{c}1.582 \\
0.6634\end{array}$ \\
\hline
\end{tabular}

Table II. 2

\begin{tabular}{|c|c|c|c|c|}
\hline & (1) & (2) & (3) & (4) \\
\hline income per capita & $\begin{array}{c}0.997 \\
(1.281)\end{array}$ & $\begin{array}{c}1.416 \\
(1.259)\end{array}$ & $\begin{array}{c}1.724 \\
(1.262)\end{array}$ & $\begin{array}{c}1.748 \\
(1.271)\end{array}$ \\
\hline interest rate & $\begin{array}{l}-0.216^{* *} \\
(0.0964)\end{array}$ & $\begin{array}{c}-0.168^{*} \\
(0.0934)\end{array}$ & $\begin{array}{l}-0.203^{* *} \\
(0.0954)\end{array}$ & $\begin{array}{c}-0.205^{* *} \\
(0.0965)\end{array}$ \\
\hline demographics & $\begin{array}{l}0.0698 \\
(0.136)\end{array}$ & $\begin{array}{c}0.211 \\
(0.151)\end{array}$ & $\begin{array}{l}0.261^{*} \\
(0.152)\end{array}$ & $\begin{array}{l}0.278^{*} \\
(0.154)\end{array}$ \\
\hline house prices & $\begin{array}{l}0.346 * * * \\
(0.0207)\end{array}$ & $\begin{array}{c}0.303 * * * \\
(0.0228)\end{array}$ & $\begin{array}{l}0.304^{* * *} \\
(0.0228)\end{array}$ & $\begin{array}{l}0.307 * * * \\
(0.0231)\end{array}$ \\
\hline unemployment & & $\begin{array}{c}-0.227^{* * *} \\
(0.0631)\end{array}$ & $\begin{array}{c}-0.240 * * * \\
(0.0640)\end{array}$ & $\begin{array}{c}-0.228^{* * *} \\
(0.0664)\end{array}$ \\
\hline rule of law & & & $\begin{array}{c}3.121 \\
(2.293)\end{array}$ & $\begin{array}{c}3.038 \\
(2.317)\end{array}$ \\
\hline mortgage deductibility & & & & $\begin{array}{c}0.259 \\
(0.729)\end{array}$ \\
\hline $\mathrm{N}$ & 221 & 221 & 221 & 221 \\
\hline
\end{tabular}


Table II. 3

\begin{tabular}{|c|c|c|c|c|c|}
\hline & (1) & (2) & (3) & (4) & (5) \\
\hline debt overhang lag & $\begin{array}{c}0.0265 \\
(0.0573)\end{array}$ & $\begin{array}{c}0.0265 \\
(0.0590)\end{array}$ & $\begin{array}{r}-0.0154 \\
(0.0608)\end{array}$ & $\begin{array}{r}-0.0281 \\
(0.0609)\end{array}$ & $\begin{array}{r}-0.0325 \\
(0.0606)\end{array}$ \\
\hline income per capita & $\begin{array}{l}0.0953 \\
(1.943)\end{array}$ & $\begin{array}{l}0.0953 \\
(1.769)\end{array}$ & $\begin{array}{c}0.725 \\
(1.835)\end{array}$ & $\begin{array}{c}0.981 \\
(1.839)\end{array}$ & $\begin{array}{c}1.014 \\
(1.845)\end{array}$ \\
\hline interest rate & $\begin{array}{c}-0.262^{* * *} \\
(0.0948)\end{array}$ & $\begin{array}{c}-0.262^{* *} \\
(0.119)\end{array}$ & $\begin{array}{c}-0.243^{* *} \\
(0.119)\end{array}$ & $\begin{array}{c}-0.281^{* *} \\
(0.123)\end{array}$ & $\begin{array}{c}-0.271 * * \\
(0.125)\end{array}$ \\
\hline demographics & $\begin{array}{c}0.117 \\
(0.239)\end{array}$ & $\begin{array}{c}0.117 \\
(0.190)\end{array}$ & $\begin{array}{c}0.286 \\
(0.215)\end{array}$ & $\begin{array}{c}0.330 \\
(0.214)\end{array}$ & $\begin{array}{c}0.351 \\
(0.216)\end{array}$ \\
\hline house prices & $\begin{array}{l}0.382^{* * *} \\
(0.0300)\end{array}$ & $\begin{array}{l}0.382^{* * *} \\
(0.0322)\end{array}$ & $\begin{array}{c}0.367^{* * *} \\
(0.0323)\end{array}$ & $\begin{array}{c}0.367^{* * *} \\
(0.0320)\end{array}$ & $\begin{array}{c}0.372^{* * *} \\
(0.0323)\end{array}$ \\
\hline unemployment & & & $\begin{array}{c}-0.148^{*} \\
(0.0802)\end{array}$ & $\begin{array}{c}-0.178^{* *} \\
(0.0792)\end{array}$ & $\begin{array}{c}-0.162^{*} \\
(0.0829)\end{array}$ \\
\hline rule of law & & & & $\begin{array}{c}4.130 \\
(2.961)\end{array}$ & $\begin{array}{c}3.916 \\
(3.024)\end{array}$ \\
\hline mortgage deductibility & & & & & $\begin{array}{c}0.856 \\
(1.024)\end{array}$ \\
\hline $\mathrm{N}$ & 221 & 221 & 221 & 221 & 221 \\
\hline
\end{tabular}

Table II. 4

\begin{tabular}{|c|c|c|c|c|c|}
\hline & (1) & (2) & (3) & (4) & (5) \\
\hline cumulative debt overhang lag & $\begin{array}{c}0.885^{* * *} \\
(0.0325)\end{array}$ & $\begin{array}{c}0.894^{* * *} \\
(0.0438)\end{array}$ & $\begin{array}{l}0.908^{* * *} \\
(0.0453)\end{array}$ & $\begin{array}{c}0.899^{* * *} \\
(0.0451)\end{array}$ & $\begin{array}{c}0.792^{* * *} \\
(0.0862)\end{array}$ \\
\hline GDP growth & $\begin{array}{c}44.48^{* * *} \\
(12.21)\end{array}$ & $\begin{array}{c}57.21^{* * *} \\
(15.86)\end{array}$ & $\begin{array}{c}75.10^{* * *} \\
(17.11)\end{array}$ & $\begin{array}{c}73.09 * * * \\
(17.13)\end{array}$ & $\begin{array}{c}82.39 * * * \\
(18.98)\end{array}$ \\
\hline CIT & & $\begin{array}{c}0.158 \\
(0.115)\end{array}$ & $\begin{array}{c}0.320^{* *} \\
(0.154)\end{array}$ & $\begin{array}{l}0.290^{*} \\
(0.151)\end{array}$ & $\begin{array}{l}0.427^{*} \\
(0.221)\end{array}$ \\
\hline ROA & & & $\begin{array}{c}-38.09^{* *} \\
(15.58)\end{array}$ & $\begin{array}{c}-47.68^{* * *} \\
(17.33)\end{array}$ & $\begin{array}{c}-112.3^{* * *} \\
(40.37)\end{array}$ \\
\hline thin capitalization & & & & $\begin{array}{c}-2.147^{* *} \\
(0.981)\end{array}$ & $\begin{array}{c}-3.770^{* * *} \\
(1.093)\end{array}$ \\
\hline insolvency & & & & & $\begin{array}{c}-0.316^{* *} \\
(0.128)\end{array}$ \\
\hline $\mathrm{N}$ & 261 & 229 & 198 & 198 & 137 \\
\hline $\begin{array}{l}\text { J-statistic } \\
\text { (p-value) }\end{array}$ & & $\begin{array}{r}0.228 \\
0.8921 \\
\end{array}$ & $\begin{array}{c}0.794 \\
0.6724 \\
\end{array}$ & $\begin{array}{c}1.095 \\
0.5785 \\
\end{array}$ & $\begin{array}{c}2.526 \\
0.64 \\
\end{array}$ \\
\hline
\end{tabular}

\section{CInternational Monetary Fund. Not for Redistribution}


Table II. 5

\begin{tabular}{lccccc}
\hline & $(1)$ & $(2)$ & $(3)$ & $(4)$ & $(5)$ \\
GDP growth & & & & & \\
& $40.58^{* * *}$ & $41.37^{* * *}$ & $57.16^{* * *}$ & $55.73^{* * *}$ & $60.30^{* * *}$ \\
& $(10.81)$ & $(10.85)$ & $(12.75)$ & $(12.24)$ & $(13.24)$ \\
CIT & & & & & \\
& & 3.630 & 8.357 & 4.517 & 5.593 \\
& & $(7.709)$ & $(9.777)$ & $(9.475)$ & $(12.62)$ \\
ROA & & & & \\
& & & -21.77 & $-27.91^{*}$ & $-68.52^{* * *}$ \\
thin capitalization & & & $(14.28)$ & $(14.24)$ & $(25.28)$ \\
& & & & $-1.971^{* *}$ & $-2.583^{*}$ \\
insolvency & & & & $(0.888)$ & $(1.392)$ \\
& & & & & $-0.218^{* * *}$ \\
$\mathrm{~N}$ & & & & & $10.0561)$ \\
\hline
\end{tabular}

Table II. 6

\begin{tabular}{|c|c|c|c|c|c|}
\hline & (1) & (2) & (3) & (4) & (5) \\
\hline debt overhang lag & $\begin{array}{c}0.156^{* *} \\
(0.0731)\end{array}$ & $\begin{array}{c}0.152^{* *} \\
(0.0729)\end{array}$ & $\begin{array}{c}0.129 \\
(0.0957)\end{array}$ & $\begin{array}{c}0.109 \\
(0.0986)\end{array}$ & $\begin{array}{c}0.145^{* *} \\
(0.0720)\end{array}$ \\
\hline GDP growth & $\begin{array}{c}43.74 * * * \\
(11.66)\end{array}$ & $\begin{array}{c}44.64^{* * *} \\
(11.85)\end{array}$ & $\begin{array}{c}60.91^{* * *} \\
(16.69)\end{array}$ & $\begin{array}{c}60.03^{* * *} \\
(16.47)\end{array}$ & $\begin{array}{c}67.03^{* * *} \\
(8.301)\end{array}$ \\
\hline CIT & & $\begin{array}{c}9.003 \\
(11.46)\end{array}$ & $\begin{array}{c}15.40^{* * *} \\
(5.231)\end{array}$ & $\begin{array}{l}12.40^{* *} \\
(5.073)\end{array}$ & $\begin{array}{c}17.67 \\
(22.91)\end{array}$ \\
\hline ROA & & & $\begin{array}{c}-30.71^{* *} \\
(15.03)\end{array}$ & $\begin{array}{c}-40.50^{* * *} \\
(15.25)\end{array}$ & $\begin{array}{c}-83.66^{* *} \\
(40.57)\end{array}$ \\
\hline thin capitalization & & & & $\begin{array}{c}-1.853^{* *} \\
(0.730)\end{array}$ & $\begin{array}{c}-3.823^{* *} \\
(1.922)\end{array}$ \\
\hline insolvency & & & & & $\begin{array}{c}-0.291^{* * *} \\
(0.0442)\end{array}$ \\
\hline $\mathrm{N}$ & 261 & 261 & 223 & 223 & 152 \\
\hline
\end{tabular}

C)International Monetary Fund. Not for Redistribution 


\section{REFERENCES}

Acemoglu, D. (2005). "Politics and Economics in Weak and Strong States," Journal of Monetary Economics, 52, 1199-1226.

Acemoglu, D. and J. Robinson, (2016) Paths to Inclusive Political Institutions, http://economics.mit.edu/faculty/acemoglu/paper

Aghion, P. and P. Bolton (1992). "An incomplete contracts approach to corporate bankruptcy,” Review of Economic Studies 59, 473-494.

Albuquerque, B., U. Baumann, and G. Krustev (2015). "US household deleveraging following the Great Recession - a model-based estimate of equilibrium debt," The B.E. Journal of Macroeconomics 15(1), 255-307.

Almeida, H. and M. Campello (2010). "Financing Frictions and the Substitution Effect Between Internal and External Funds," Journal of Financial and Quantitative Analysis 45, 589-622

Almeida, H., M. Campello, and C. Liu (2006). "The financial accelerator: Evidence from the international housing markets," Review of Finance, 10(3), 321-352.

Aoki, K., Proudman, J., and Vlieghe, G. (2004). "House Prices, Consumption, and Monetary Policy: A Financial Accelerator Approach," Journal of Financial Intermediation 13, 414-35.

Arrow, K., P. Dasgupta, L. Goulder, G. Daily, P. Ehrlich, G. Heal, S. Levin, K.-G. Maler, S. Schneider, D. Starrett, and Walker, B. (2004). "Are We Consuming Too Much?," Journal of Economic Perspectives, No. 18 (3), 147-72.

Barnes, S. and G. Young (2003). "The rise in US household debt: assessing its causes and sustainability," Bank of England Working Paper, no 206.

Bernanke, B., M. Gertler, and S. Gilchrist (1999). "The Financial Accelerator in a Quantitative Business Cycle Framework," in Handbook of Macroeconomics, Volume 1C, Handbooks in Economics, vol. 15. Amsterdam: Elsevier, 1341-93.

Blanchard, O. and D. Leigh (2013). "Growth Forecast Errors and Fiscal Multipliers," American Economic Review: Papers and Proceedings, vol. 103(3), 117-120.

Blouin, J., H. Huizinga, L. Laeven and G. Nicodème (2014). "Thin Capitalization Rules and Multinational Firm Capital Structure," IMF Working Paper, No. 14.

Bruno, G. (2005). "Approximating the Bias of the LSDV Estimator for Dynamic Unbalanced Panel Data Models," Economics Letters, 87, 361-6. 
Campbell, J. and J Rocco (2003). "Household risk management and optimal mortgage choice," Quarterly Journal of Economics, vol 118, no 4, 1449-94.

Carroll, C., and W. Dunn (1997). "Unemployment Expectations, Jumping (S,s) Triggers, and Household Balance Sheets," in Ben Bernanke and Julio Rotemberg, eds., NBER Macroeconomics Annual. Cambridge, MA: MIT Press: 165-229.

Cerutti, E., J. Dagher, and G. Dell'Ariccia (2015). "Housing Finance and Real-Estate Booms: A Cross-Country Perspective," IMF Staff Discussion Note, 15/12.

Cottarelli, C., G. Dell'Ariccia, and I. Vladkova-Hollar (2005). "Early Birds, Late Risers, and Sleeping Beaties: Bank Credit Growth to the Private Sector in Central and Eastern Europe and in the Balkans," Journal of Banking and Finance, vol. 29, No. 1, 83-104

Massimo C., R. De Bonis, and S. Piermattei (2014). "The determinants of household debt: a cross-country analysis," Temi di discussione 989, Bank of Italy, Economic Research and International Relations Area

Cuerpo, C., I. Drumond, J. Lendvai, P. Pontuch, and R. Raciborski (2015). "Private Sector Deleverage in Europe," Economic Modelling, No 44, 372-83

Davies, J., S. Sandström, A. Shorrocks and E. Wolff (2011). "The Level and Distribution of Global Household Wealth," Economic Journal, 121, March, 223-54

Deaton, A. (1992) Understanding Consumption, Oxford University Press, Oxford, UK.

Debelle, G. (2004). "Macroeconomic Implications of Rising Household Debt,” BIS Working Paper, No. 153 (June).

Debrun, X. and T. Kinda (2016). "That Squeezing Feeling: The Interest Burden and Public Debt Stabilization," International Finance, vol. 19(2), 147-178

De Jong, A., M. Verbeek, and P. Verwijmeren (2011). "Firms' debt-equity decisions when the static tradeoff theory and the pecking order theory disagree," Journal of Banking and Finance, 35 (5), 1303-1314

Demirgüç-Kunt, A. and V. Maksimovic (1999). "Institutions, financial markets and firm debt maturity," Journal of Financial Economics 54, 295-336

De Mooij, R. and M. Keen (2016). "Debt, Taxes, and Banks," Journal of Money, Credit and Banking, Vol. 48, No. 1, 5-33.

De Mooij, R., M. Keen, and M. Orihara (2014). "Taxation, Bank Leverage, and Financial crises." In Taxation and Regulation of the Financial Sector, edited by Ruud A. de Mooij and Gaetan Nicodeme, 235-60. Cambridge, MA: MIT Press. 
Djankov, S., C. McLiesh, and A. Shleifer (2007). "Private credit in 129 countries," Journal of Financial Economics, Vol. 84, 299-329.

Dynan K. E. and D. L. Kohn (2007). "The Rise in U.S. Household Indebtedness: Causes and Consequences," Finance and Economics Discussion Series, n. 37, Federal Reserve Board.

European Central Bank (2013). "Corporate Finance and Economic Activity,” ECB Occasional Paper, No 151

Fama, E. and K. French (2002). "Testing Trade-off and Pecking Order Predictions about Dividends and Debt," The Review of Financial Studies, Vol. 15, No 1, 1-33.

Fan, J., S. Titman, and G. Twite (2010). “An International Comparison of Capital Structure and Debt Maturity Choices," NBER Working Papers, No 16445, The National Bureau of Economic Research.

Feld, L., Heckemeyer, J. and M. Overesch (2013). "Capital Structure Choice and Company taxation: A Meta-study," Journal of Banking and Finance, No. 37, 2850-2886

Fernandez-Corugedo, E. and J. Muellbauer (2006). "Consumer credit conditions in the United Kingdom,” Bank of England Working Paper, 314.

Frank, M., and V. Goyal (2008). "Trade-off and Pecking Order Theories of Debt," In Espen Eckbo (ed.) The Handbook of Empirical Corporate Finance, Elsevier Science, Chapter 12, 135-197.

Friedman, M (1957). A theory of the consumption function, Princeton University Press.

Giannetti, M. (2003). "Do Better Institutions Mitigate Agency Problems? Evidence from Corporate Finance Choices," The Journal of Financial and Quantitative Analysis, Vol. 38, No 1, March, 185-212.

Graham, J. (1996). "Proxies for the corporate marginal tax rate," Journal of Financial Economics, Vol. 42, No 2, October, 187-221.

Graham, J. (2003). “Taxes and corporate finance: A review,” Review of Financial Studies 16, 1074-1128.

Graham, J. (2006). "A Review of Taxes and Corporate Finance," Foundations and Trends in Finance, 1, 573-691.

Graham, J. and C. Harvey (2001). "The theory and practice of corporate finance: Evidence from the field," Journal of Financial Economics 60, 187-243. 
Hall, R (1978). "Stochastic implications of the life cycle-permanent income hypothesis: theory and evidence," Journal of Political Economy, December, 971-87.

Hall, G., P. Hutchinson, P. and N. Michaelas (2004). "Determinants of the Capital Structures of European SMEs," Journal of Business Finance \& Accounting, 31, 711-728.

Hart, O. and J. Moore (1994). "A theory of debt based on the inalienability of human capital," Quarterly Journal of Economics 109, 841-879.

Hart O. and J. Moore (1998). "Default and renegotiation: A dynamic model of debt," Quarterly Journal of Economics 113, 1-42.

International Monetary Fund (2016). “Tax Policy, Leverage and Macroeconomic Stability,” IMF Policy Paper 16/151, International Monetary Fund: Washington, DC, USA

International Monetary Fund (2003). "Public Debt in Emerging Markets: Is it Too High?," World Economic Outlook, September, International Monetary Fund: Washington, DC, USA

Jaffee, D. T. Russell (1976). "Imperfect Information, Uncertainty, and Credit Rationing," The Quarterly Journal of Economics, Vol. 90, No. 4., 651-666.

Jameson, M., S. Dewan, and C. Sirmans (1992). "Measuring Welfare Effects of 'Unbundling' Financial Innovations: The Case of Collateralized Mortgage Obligations," Journal of Urban Economics 31 (January): 1-13.

Jappelli, T and M Pagano (1989). "Consumption and capital market imperfections: an international comparison," American Economic Review, vol 79, 1088-105.

Jappelli, T. and L. Pistaferri (2007). "Do People Respond to Tax Incentives? An analysis of the Italian Reform of the Deductibility of Home Mortgage Interest," European Economic Review, No. 51, 247-271.

Jorda, O., M. Schularick, and A. Taylor.(2016). "Sovereigns versus Banks: Credit, Crises, and Consequences," Journal of the European Economic Association 14 (1), 45-79.

Judson, R., and A. Owen (1999). "Estimating Dynamic Panel Data Models: A Guide for Macroeconomists," Economics Letters, 65(1), 9-15.

Kolari, J., D. Fraser, and A. Anari (1998). "The Effects of Securitization on Mortgage Market Yields: A Cointegration Analysis," Real Estate Economics 26, 677-93.

Ludvigson, S. (1999). "Consumption and credit: a model of time-varying liquidity constraints," Review of Economics and Statistics, vol 81, no 3, 434-47.

Lorenzoni, G. (2008). “Inefficient Credit Booms," Review of Economic Studies 75 (3), 809833. 
Miles, D. (1992). "Housing markets, consumption and financial liberalisation," European Economic Review, vol 36, 1093-127.

Modigliani, F., and R. Brumberg (1954) "Utility analysis and the consumption function: an interpretation of cross-section data," in Kenneth K. Kurihara, ed., Post- Keynesian Economics, New Brunswick, NJ. Rutgers University Press. 388-436.

Modigliani, F. and M. Miller (1958). "The Cost of Capital, Corporation Finance and the Theory of Investment," American Economic Review, Vol. 48, No 3, June, 261-297.

Muellbauer, J. (1994). "The Assessment: Consumer Expenditure," Oxford Review of Economic Policy, 10, 1-41.

Myers, S. (1977). "Determinants of corporate borrowing," Journal of Financial Economics, Vol. 5, No 2, November, 147-175.

Myers, S. (1984). “The Capital Structure Puzzle,” Journal of Finance, Vol. 39, No 3, July, 574-592.

Myers, S. and N. Majluf (1984). "Corporate financing and investment decisions when firms have information that investors do not have," Journal of Financial Economics, Vol. 13, No 2, June, 187-221.

Poterba, J. (1984). "Tax Subsidies to Owner Occupied Housing: An Asset-Market Approach," Quarterly Journal of Economics 99 (4), 729-752.

Poterba, J. and T. Sinai (2011). "Revenue Costs and Incentive Effects of the Mortgage Interest Deduction for Owner-Occupied Housing," National Tax Journal, 64 (2, Part 2), 531-564.

Rajan, R. and L. Zingales (1995). "What Do We Know about Capital Structure? Some Evidence from International Data," The Journal of Finance, Vol. 50, No 5, December, 1421-1460.

Sahay, R., M. Cihak, P. N'Diaye, A. Barajas, R. Bi, D. Ayala, Y. Gao, A. Kyobe, L. Nguyen, C. Saborowski, K. Svirydzenka, and S. Yousefi (2015). "Rethinking Financial Deepening: Stability and Growth in Emerging Market," IMF Staff Discussion Note, $15 / 08$

Stiglitz J. and Weiss, A. (1981). "Credit Rationing in Markets with Imperfect Information," American Economic Review, 71, 3, 393-410.

Sutherland, D. and P. Hoeller (2012). "Debt and Macroeconomic Stability: An Overview of the Literature and Some Empirics," OECD Economics Department Working Papers, No. 1006 
Townsend, R. (1979). "Optimal contracts and competitive markets with costly state verification," Journal of Economic Theory 21, 265-293.

Tudela, M. and G. Young (2005). "The determinants of household debt and balance sheets in the United Kingdom," Bank of England Working Paper, No. 266. 